\title{
Effects of halofenate and probenecid on serum lipids and uric acid in hyperlipidemic, hyperuricemic adults
}

\begin{abstract}
The effect of halofenate was compared with that of probenecid in overweight patients with hyperlipidemia and hyperuricemia. Halofenate induced a prompt and sustained lowering $(12.7 \%)$ of serum triglycerides, but probenecid induced no change in serum triglycerides. Both drugs promptly induced reductions (32\%) of serum uric acid. Halofenate induced a $13.3 \%$ increase in serum lactic dehydrogenase. Both drugs induced mild but significant decreases in hemoglobin and in serum albumin, but the between-group differences were not significant. When the effects of the two drugs were divided into subgroups below and above the baseline median value for serum triglycerides, cholesterol, uric acid, and percent ideal body weight, a differential effect on serum triglycerides was noted when serum uric acid and percent ideal body weight were taken as the segregating variables. There was a greater serum triglyceride decline after halofenate in the high-weight group than in the lower-weight group $(-25.5 \% \mathrm{vs}+2.7 \%)$, and a greater serum triglyceride decline in the high uric acid group than in the lower uric acid group $(-22.6 \%$ vs $-2.4 \%$ ). The divergent behavior in regard to initial percent ideal body weight and uric acid level may account for the greater halofenate-induced reductions in serum triglycerides reported by others. In the halofenate group, there was a significant correlation between percent change in triglycerides and percent calories from alcohol. Further study of these responses may provide increased understanding of halofenate action and of the pathogenesis of some types of hyperlipidemia.
\end{abstract}

David R. Bassett, M.D., William M. Mikkelsen, M.D., Robert B. Buckingham, M.D., Walter D. Block, Ph.D., Mohammed Sidiq, M.D., Ali Shakibai, M.D., Ralph DiGaetano, M.A., and Ling-ling Liou, M.P.H. Ann Arbor, Mich. Hyperlipidemia Program, Hypertension Division and Rheumatology Division, Department of Internal Medicine, University of Michigan Medical Center

Halofenate, 2-aceto amidoethyl ( $p$-chlorophenyl) ( $m$-trifluoromethylphenoxy) acetate, is an investigational hypolipidemic drug which

\footnotetext{
Supported by Merck Sharp \& Dohme, West Point, Pa.

Received for publication July 20, 1976.

Accepted for publication April 30, 1977.

Reprint requests to: David R. Bassett, M.D., R6669 Kresge Medical Research Bldg. I, University of Michigan Medical Center,
} Ann Arbor, Mich. 48109. has also been demonstrated to be an effective uricosuric agent. Our study was designed to compare the effects of halofenate and probenecid on serum lipid and uric acid values and on certain monitoring parameters in adults with hyperlipidemia and uricemia. We also sought to determine whether halofenate and probenecid induced different responses in serum cholesterol, triglycerides and uric acid in 


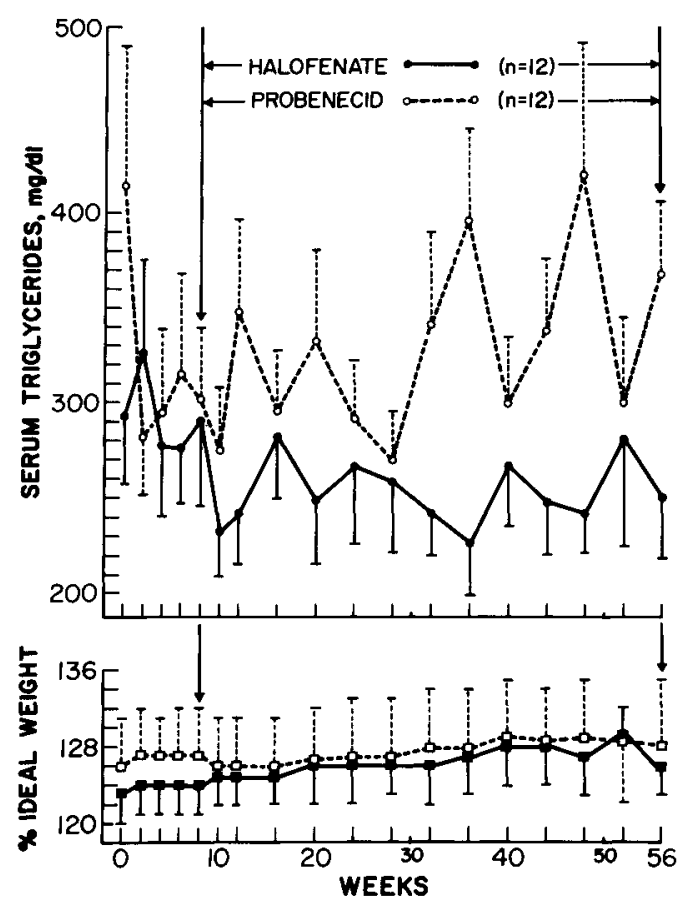

Fig. 1. Effect of halofenate and probenecid on serum triglycerides (mean $\pm \mathrm{SE}$ ). Baseline period: wk 0 to 8 .

patients with baseline levels of cholesterol, triglycerides, uric acid and percent ideal body weight above the median value for the group and in patients with baseline levels for these parameters below the median value for the group.

\section{Materials and methods}

Patients between the ages of 21 and $65 \mathrm{yr}$ were selected on the basis of elevation of both serum uric acid $(7 \mathrm{mg} / 100 \mathrm{ml}$ or over for men and $6 \mathrm{mg} / 100 \mathrm{ml}$ or over for women) and serum lipids (mean untreated serum cholesterol of 275 $\mathrm{mg} / 100 \mathrm{ml}$ or over and/or mean untreated fasting serum triglycerides of $150 \mathrm{mg} / 100 \mathrm{ml}$ or over) and their ability to participate in a $56-\mathrm{wk}$ study. The following led to exclusion from the study: pregnancy, lactation, a history of uric acid renal stone formation, gouty nephropathy, requirement for long-term salicylate therapy, serious alcoholism, significant impairment of liver or renal function, recent severe or poorly controlled cardiac disease, any severe disease, and a history of significant prior adverse reaction to probenecid or halofenate.

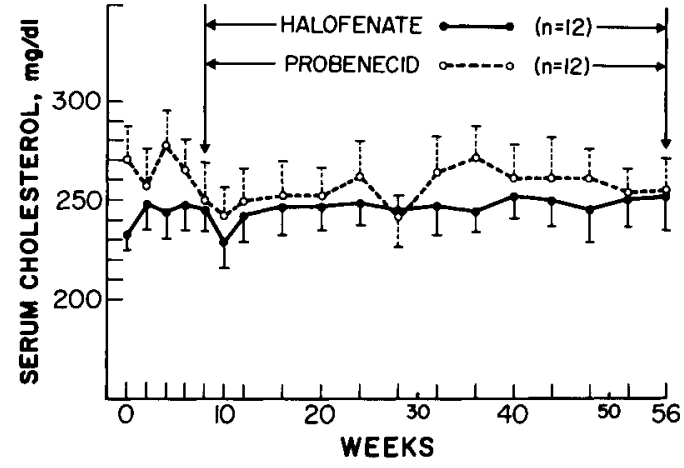

Fig. 2. Effect of halofenate and probenecid on serum cholesterol (mean $\pm \mathrm{SE}$ ). Baseline period: wk 0 to 8 .

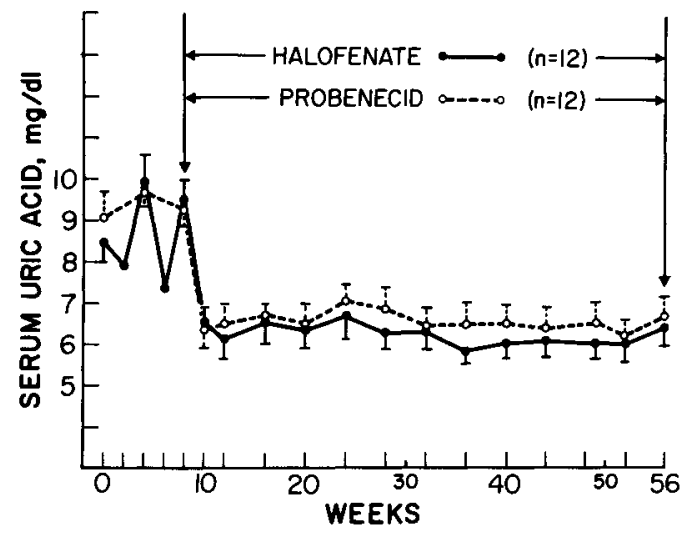

Fig. 3. Effect of halofenate and probenecid on serum uric acid (mean $\pm \mathrm{SE}$ ). Baseline period: wk 0 to 8 .

Drug therapy was preceded by a control period of 8 wk during which patients were seen at 2-wk intervals and baseline clinical and laboratory data were obtained. All patients had careful ophthalmologic examinations during the control period and again after 48 wk of treatment.

Patients were separated into four diagnostic categories as follows: (1) patients under $55 \mathrm{yr}$ without clinical evidence of atherosclerosis; (2) patients under $55 \mathrm{yr}$ with atherosclerotic complications; (3) patients $55 \mathrm{yr}$ and over with no atherosclerotic complications; (4) patients $55 \mathrm{yr}$ and over with atherosclerotic complications. Twenty-six patients who met the criteria for entry into the study were randomly assigned to receive either halofenate or probenecid. The drugs were supplied as identical-appearing 500 -mg tablets. Dosage was based on the pa- 
Table I. Details of patients studied

\begin{tabular}{|c|c|c|c|c|c|c|c|c|c|}
\hline $\begin{array}{c}\text { Patient } \\
\text { Serial } \\
\text { No. }\end{array}$ & $\begin{array}{l}\text { Age } \\
(y r)\end{array}$ & Sex & Race & $\begin{array}{c}\text { Height } \\
\text { (in) }\end{array}$ & $\begin{array}{l}\text { Weight* } \\
\quad(l b)\end{array}$ & $\begin{array}{l}\% \text { ideal } \\
\text { weight* }\end{array}$ & $\begin{array}{c}\text { Serum } \\
\text { uric } \\
\text { acid* } \\
(\mathrm{mg} / 100 \mathrm{ml})\end{array}$ & $\begin{array}{c}\text { Serum } \\
\text { cholesterol } \\
(\mathrm{mg} / 100 \mathrm{ml})\end{array}$ & $\begin{array}{c}\text { Fasting } \\
\text { serum } \\
\text { trigly- } \\
\text { ceride } \\
(\mathrm{mg} / 100 \mathrm{ml})\end{array}$ \\
\hline \multicolumn{10}{|c|}{ Halofenate group } \\
\hline 1. 1048 & 52 & M & W & 70 & 227 & 144 & 10.4 & 243 & 350 \\
\hline 2. 1051 & 52 & $\mathrm{~F}$ & W & 65 & 173 & 132 & 6.5 & 276 & 223 \\
\hline 3. 1052 & 48 & M & W & 68 & 196 & 131 & 10.2 & 248 & 232 \\
\hline 4. 1062 & 50 & M & W & 63 & 163 & 125 & 10.2 & 210 & 628 \\
\hline 5. 1064 & 46 & $\mathrm{M}$ & W & 71 & 185 & 114 & 12.0 & 212 & 278 \\
\hline 6. 1080 & 43 & M & W & 69 & 188 & 123 & 8.5 & 219 & 329 \\
\hline 7. 1083 & 29 & M & W & 69 & 183 & 120 & 7.5 & 246 & 152 \\
\hline 8. 2010 & 43 & $\mathrm{~F}$ & W & 62 & 142 & 119 & 6.8 & 317 & 327 \\
\hline 9. 2013 & 48 & M & W & 68 & 151 & 101 & 10.9 & 228 & 189 \\
\hline 10. 3045 & 54 & M & W & 72 & 199 & 120 & 8.5 & 177 & 185 \\
\hline 11. 3050 & 58 & M & W & 74 & 225 & 128 & 11.4 & 267 & 245 \\
\hline 12. 4014 & 64 & M & W & 69 & 186 & 122 & 10.1 & 284 & 314 \\
\hline Mean & 48.9 & & & 68.3 & 185.0 & 123.9 & 9.42 & 244.0 & 292.6 \\
\hline$\pm \mathrm{SE}$ & 2.5 & & & 3.7 & 1.0 & 3.4 & 0.21 & 4.7 & 15.0 \\
\hline \multicolumn{10}{|c|}{ Probenecid group } \\
\hline 1. 1049 & 54 & $\mathrm{M}$ & W & 67 & 212 & 146 & 8.7 & 205 & 362 \\
\hline 2. 1050 & 46 & M & W & 69 & 167 & 109 & 9.2 & 179 & 184 \\
\hline 3. 1053 & 51 & $\mathrm{~F}$ & W & 66 & 158 & 117 & 7.7 & 360 & 201 \\
\hline 4. 1063 & 46 & M & B & 69 & 235 & 155 & 12.3 & 208 & 294 \\
\hline 5. 1065 & 41 & $M$ & $\mathrm{~W}$ & 68 & 215 & 144 & 10.5 & 289 & 609 \\
\hline 6. 1081 & 28 & M & W & 74 & 204 & 116 & 8.9 & 257 & 193 \\
\hline 7. 1084 & 32 & M & W & 75 & 209 & 116 & 8.1 & 258 & 323 \\
\hline 8. 2011 & 45 & $M$ & W & 71 & 207 & 127 & 9.5 & 366 & 405 \\
\hline 9. 3044 & 61 & $\mathrm{M}$ & B & 65 & 179 & 132 & 10.1 & 271 & 323 \\
\hline 10. 3051 & 56 & $\mathrm{M}$ & W & 68 & 191 & 128 & 9.5 & 239 & 307 \\
\hline 11. 3052 & 56 & M & W & 70 & 199 & 127 & 9.0 & 303 & 293 \\
\hline 12. 4015 & 65 & M & W & 65 & 131 & 96 & 9.2 & 237 & 179 \\
\hline Mean & 48.4 & & & 68.9 & 192.3 & 126.7 & 9.39 & 264.3 & 323.3 \\
\hline$\pm \mathrm{SE}$ & 3.2 & & & 0.9 & 3.8 & 4.6 & 0.14 & 7.1 & 15.7 \\
\hline $\mathrm{p}$ value & NS + & & & $\mathrm{NS} \dagger$ & NSt & $\mathrm{NS}+$ & NS† & NS $\dagger$ & $\mathrm{NS} \ddagger$ \\
\hline
\end{tabular}

CHD: coronary heart disease; CV: cerebral vascular disease; PV: peripheral vascular disease; + : with disease; -: without disease.

*Value: average of all baseline values.

$\dagger$ Student's $t$ test, halofenate group vs probenecid group; NS: not significant $(p>0.05)$.

$\ddagger$ Student's $t$ test performed on log serum triglyceride value; Mann-Whitney $U$ test also NS.

tient's actual weight as follows: under $60 \mathrm{~kg}$, $500 \mathrm{mg}$ once daily; 60 to $99 \mathrm{~kg}, 1,000 \mathrm{mg}$ once daily; $100 \mathrm{~kg}$ and above, $1,500 \mathrm{mg}$ once daily. Patients were seen 2 and 4 wk after the starting of treatment and at 4-wk intervals thereafter. At each 4-wk visit they were required to return all unused medication. The tablets were counted and recorded to document compliance to the prescribed schedule. Downward dosage adjustment was permitted in the event of minor intolerance or side effects.

Uricosuric drugs, xanthine oxidase inhib- itors, and hypolipidemic drugs were not permitted. Other medication needed for the patient's well-being were continued throughout the study. Changes in such medication during the study were noted. No specific dietary regimen was prescribed, but an attempt was made to have each patient follow the same diet throughout the study. Diet histories were obtained from most patients at the start and completion of the study.

At each visit, patients' weight, blood pressure, pulse, liver size, and drug tolerance were 


\begin{tabular}{c|c|c|c|c}
\hline & \multicolumn{3}{|c|}{$\begin{array}{c}\text { Clinically } \\
\text { evident } \\
\text { Lipopro- } \\
\text { teinemia } \\
\text { type* }\end{array}$} & \multicolumn{2}{|c|}{\begin{tabular}{c} 
\\
\cline { 2 - 3 }
\end{tabular}} & $C H D$ & $C V$ & $P V$ & Gout & $\begin{array}{c}\text { Diabetes } \\
\text { mellitus }\end{array}$ \\
\hline
\end{tabular}

$\begin{array}{llllll}\text { IV } & - & - & - & + & - \\ \text { IV } & - & - & - & + & - \\ \text { IV } & - & - & - & + & - \\ \text { IV } & - & - & - & + & + \\ \text { IV } & - & - & - & + & - \\ \text { IV } & - & - & - & - & - \\ \text { IV } & - & - & - & + & - \\ \text { IIb } & + & - & - & - & + \\ \text { IV } & + & - & + & + & - \\ \text { IV } & - & - & - & + & + \\ \text { IV } & - & - & - & + & - \\ \text { IV } & - & + & - & + & -\end{array}$

$\begin{array}{llllll}\text { IV } & - & - & - & + & - \\ \text { IV } & - & - & - & + & - \\ \text { IIb } & - & - & - & - & - \\ \text { IV } & - & - & - & + & + \\ \text { IV } & - & - & - & + & - \\ \text { IV } & - & - & - & - & - \\ \text { IV } & - & - & - & - & - \\ \text { IIb } & - & + & - & + & - \\ \text { IV } & - & - & - & + & - \\ \text { IV } & - & - & - & + & - \\ \text { IV } & - & - & - & + & - \\ \text { IV } & - & - & + & \text { Prob } & -\end{array}$

noted. Percent ideal weight was based on Metropolitan Life Insurance tables (taking midpoint for medium frame). ${ }^{32}$ Laboratory evaluations included appearance of fasting serum, fasting serum cholesterol, ${ }^{8}$ triglycerides, ${ }^{7}$ uric acid, ${ }^{10}$ and lipoprotein typing. ${ }^{15}$ Hemoglobin, hematocrit, white blood cell count (WBC) and differential, platelet count, and urine were analyzed by standard techniques. Serum glucose, blood urea nitrogen, serum bilirubin, serum glutamic oxaloacetic transaminase (SGOT), (lactic dehydrogenase) (LDH), serum alkaline phosphatase, creatine phosphokinase (CPK), total serum protein, and serum albumin were determined by AutoAnalyzer (SMA 12-60). ${ }^{37}$
While 13 subjects began the study in each treatment group, one subject in the probenecid group left after 12 wk because of recurrent stomatitis possibly aggravated by probenecid and one in the halofenate group left after $4 \mathrm{wk}$ because of fever, shaking chills, gingivitis, and marked neutropenia. He was hospitalized elsewhere and halofenate was discontinued; WBC returned to normal within 12 days. Results reported here are for the 24 patients who completed the 56-wk study.

\section{Results}

Baseline studies (intergroup comparisons). Table I presents the principal clinical characteristics of the patients studied. A number of other clinical, hemodynamic, biochemical, hematologic, and other parameters measured were found not to be significantly affected.*

Effects of halofenate in group $\mathrm{H}$ or probenecid in group $P$ (within-group studies). The effects of each drug and data for each visit during the baseline period (wk 0 to 8) and for each visit during the treatment period (wk 10 to 56) were plotted. Figs. 1, 2, and 3 show mean ( \pm SE of the mean) for serum triglycerides and percent ideal weight, serum cholesterol, and serum uric acid.

To determine whether the drugs had significant effects on serum triglycerides, cholesterol, or uric acid or on biochemical, hematologic, or other parameters, baseline data were averaged. ("Baseline" will refer to the period of placebo administration, i.e., wk 0 to 8.) The 48-wk treatment period was then arbitrarily divided into weeks 10 to 24 (period A), weeks 28 to 40 (period B), and weeks 44 to 56 (period C).

Table II indicates that there was a decline in serum triglycerides $(11.7 \%)$ between the baseline period and period $\mathrm{A}$ in the group taking halofenate (group $\mathrm{H}$ ). This decline was sustained throughout the entire treatment period and averaged $12.7 \%$ for the entire period $(\mathrm{p}=$

\footnotetext{
* Summary of the various baseline parameters measured, and re sults found, are not printed here. They have been deposited in the permanent files of The C. V. Mosby Company. To obtain a photocopy, please address your request to the Journal Permissions Department, The C. V. Mosby Company, 11830 Westline Industrial Drive, St. Louis, Mo. 63141.
} 
Table II. Changes observed in metabolic parameters in patients receiving halofenate or probenecid (intragroup comparisons by paired t test)

\begin{tabular}{|c|c|c|c|c|c|}
\hline \multirow[b]{2}{*}{ Parameter } & \multirow{2}{*}{$\begin{array}{c}\text { Baseline } \\
\text { period } \\
(0-8 w k)\end{array}$} & \multicolumn{3}{|c|}{ Treatment periods $* \dagger$} & \multirow{2}{*}{$\begin{array}{c}\text { Total } \\
\text { treatment } \\
\text { period } \\
A-C \\
(10-56 w k)\end{array}$} \\
\hline & & $\begin{array}{c}A \\
(10-24 w k)\end{array}$ & $\begin{array}{c}B \\
(28-40 w k)\end{array}$ & $\begin{array}{c}C \\
(44-56 w k)\end{array}$ & \\
\hline \multicolumn{6}{|l|}{ Halofenate group } \\
\hline $\begin{array}{l}\text { Serum triglycerides } \\
(\mathrm{mg} / 100 \mathrm{ml} \ddagger) \\
\text { p value }\end{array}$ & 292.6 & $258.3 \quad(88.3)$ & $253.6 \quad(86.7)$ & $252.9 \quad(86.4)$ & $\begin{array}{c}255.5 \quad(87.3) \\
0.04\end{array}$ \\
\hline $\begin{array}{l}\text { Serum cholesterol } \\
(\mathrm{mg} / 100 \mathrm{ml}) \\
\mathrm{p} \text { value }\end{array}$ & 244.0 & $243.4 \quad(99.8)$ & $247.9 \quad(101.6)$ & 250.3 (102.6) & $\begin{array}{c}246.9 \quad(101.2) \\
\text { NS§ }\end{array}$ \\
\hline $\begin{array}{l}\text { Serum uric acid } \\
\quad(\mathrm{mg} / 100 \mathrm{ml}) \\
\text { p value }\end{array}$ & 9.42 & $6.47 \quad(68.7)$ & $6.10 \quad(64.8)$ & $6.14 \quad(65.2)$ & $\begin{array}{l}6.25 \quad(66.4) \\
<0.0001\end{array}$ \\
\hline $\begin{array}{l}\% \text { ideal weight } \\
\text { p value }\end{array}$ & 123.9 & $125.6 \quad(101.4)$ & $126.7 \quad(102.2)$ & $127.8(103.1)$ & $\begin{array}{c}126.6 \quad(102.2) \\
0.04\end{array}$ \\
\hline \multicolumn{6}{|l|}{ Probenecid group } \\
\hline $\begin{array}{l}\text { Serum triglycerides } \\
\quad(\mathrm{mg} / 100 \mathrm{ml} \$) \\
\text { p value }\end{array}$ & 323.3 & $308.7 \quad(95.5)$ & $332.4 \quad(102.8)$ & $356.9(110.4)$ & $\begin{array}{c}330.7 \quad(102.3) \\
\text { NS }\end{array}$ \\
\hline $\begin{array}{l}\text { Serum cholesterol } \\
(\mathrm{mg} / 100 \mathrm{ml}) \\
\mathrm{p} \text { value }\end{array}$ & 264.3 & $252.8 \quad(95.6)$ & $260.6 \quad(98.6)$ & $259.0 \quad(98.0)$ & $\begin{array}{c}257.1 \quad(97.3) \\
\text { NS }\end{array}$ \\
\hline $\begin{array}{l}\text { Serum uric acid } \\
(\mathrm{mg} / 100 \mathrm{ml}) \\
\mathrm{p} \text { value }\end{array}$ & 9.39 & $6.62 \quad(70.5)$ & $6.61 \quad(70.4)$ & $6.48 \quad(69.0)$ & $\begin{array}{l}6.57 \quad(70.0) \\
<0.0001\end{array}$ \\
\hline $\begin{array}{l}\text { \% ideal weight } \\
\mathrm{p} \text { value }\end{array}$ & 126.7 & $(99.7)$ & $127.9 \quad(100.9)$ & $128.5 \quad(101.4)$ & $\begin{array}{c}127.5 \quad(100.6) \\
\text { NS }\end{array}$ \\
\hline
\end{tabular}

*Total treatment period was arbitrarily divided into three approximately equal time periods. Dnug therapy remained the same throughout periods $\mathrm{A}, \mathrm{B}$, and $\mathrm{C}$.

$\dagger$ Figures in parentheses $=\%$ of baseline value.

$\$$ Paired $t$ tests were performed on log-transformed data.

§NS: not significant; $\mathrm{p}>0.05$.

0.04). (See below for analysis of factors relating to the wide variability in individual triglyceride responses in group $\mathrm{H}$.) Halofenate did not induce a significant change in serum cholesterol concentration but it did induce a decline in serum uric acid concentration of $31.3 \%$ in period $\mathrm{A}$. This decline was sustained throughout the remaining period, averaging $33.6 \%(\mathrm{p}<$ 0.0001 ). A mild gradual increase in weight was noted, reaching $3.1 \%$ in period $\mathrm{C}$ and averaging $2.2 \%$ for the entire treatment period $(\mathrm{p}=$ $0.04)$.

The effect of halofenate on various biochemical, hematologic, and hemodynamic parameters and its effect on ophthalmologic and electrocardiographic status were tested with the use of paired $t$ test analysis (or contingency table type of analysis in the case of categoric data). In patients receiving halofenate, significant reductions occurred (Table III) in the following parameters in one or more of periods $\mathrm{A}, \mathrm{B}$, and $\mathrm{C}$ : fasting serum glucose (average $8.7 \%$ reduction, periods $\mathrm{A}$ to $\mathrm{C}$ ); total protein $(2.9 \%$ decline in period $\mathrm{B})$; serum albumin $(13.2 \%$ decline, periods $\mathrm{A}$ to $\mathrm{C})$; bilirubin ( $51 \%$ decline, periods $\mathrm{A}$ to $\mathrm{C})$; hematocrit $(3.0 \%$ decline in period $\mathrm{C})$; hemoglobin $(6.8 \%$ decline in periods $\mathrm{B}$ and $\mathrm{C}$ ); systolic blood pressure (3.8\% decline in period A); diastolic blood pressure ( $4.8 \%$ decline in periods $\mathrm{A}$ to $\mathrm{C}$ ). Serum $\mathrm{LDH}$ was significantly elevated (average of 13.3\%) throughout the entire treatment period. There were no significant differences in the other biochemical or hematologic parameters or in 
Table III. Changes observed in biochemical, hematologic, and hemodynamic parameters in patients receiving halofenate or probenecid (intragroup comparisons)

\begin{tabular}{|c|c|c|c|c|c|c|c|c|}
\hline \multirow[b]{2}{*}{ Parameter } & \multirow{2}{*}{$\begin{array}{l}\text { Baseline } \\
\text { period } \\
(0-8 w k)\end{array}$} & \multicolumn{6}{|c|}{ Treatment periods } & \multirow{2}{*}{$\begin{array}{c}\text { Total } \\
\text { treatment } \\
\text { period, } \\
A-C \\
(10-56 w k)\end{array}$} \\
\hline & & $(10-2$ & $4 w k)$ & $\begin{array}{r}b \\
(28-4\end{array}$ & $B$ & $\begin{array}{r}C \\
(44-50\end{array}$ & $\begin{array}{l}C \\
66 w k)\end{array}$ & \\
\hline \multicolumn{9}{|l|}{ Halofenate group } \\
\hline $\begin{array}{l}\text { Fasting serum glucose } \\
\text { (mg/100 ml) } \\
\text { p value }\end{array}$ & 122.2 & 110.7 & $(90.6)$ & 106.4 & $(87.1)$ & 116.0 & (94.9) & $\begin{array}{c}111.6 \quad(91.3) \\
0.009\end{array}$ \\
\hline $\begin{array}{l}\text { Serum protein } \\
(\mathrm{gm} / 100 \mathrm{ml}) \\
\text { p value }\end{array}$ & 7.35 & 7.31 & $(99.5)$ & 7.14 & $(97.1)$ & 7.23 & $(98.4)$ & $\begin{array}{l}7.26 \quad(98.8) \\
\text { NS }\end{array}$ \\
\hline $\begin{array}{l}\text { Serum albumin } \\
(\mathrm{gm} / 100 \mathrm{ml}) \\
\mathrm{p} \text { value }\end{array}$ & 4.47 & 3.98 & $(89.0)$ & 3.80 & $(85.0)$ & 3.73 & $(83.4)$ & $\begin{array}{l}3.88 \quad(86.8) \\
<0.0001\end{array}$ \\
\hline $\begin{array}{l}\text { Serum bilirubin } \\
(\mathrm{mg} / 100 \mathrm{ml}) \\
\mathrm{p} \text { value }\end{array}$ & 1.00 & 0.50 & $(50)$ & 0.48 & $(48)$ & 0.48 & $(48)$ & $\begin{array}{c}0.49 \quad(49) \\
0.008\end{array}$ \\
\hline $\begin{array}{l}\text { Serum LDH (IU) } \\
\text { p value }\end{array}$ & 169.3 & 193.9 & $(114.5)$ & 187.2 & $(110.6)$ & 189.8 & $(112.1)$ & $\begin{array}{c}191.8(113.3) \\
0.0003\end{array}$ \\
\hline $\begin{array}{l}\text { Hematocrit }(\%) \\
\text { p value }\end{array}$ & 46.7 & 45.8 & $(98.1)$ & 45.7 & (97.9) & 45.3 & $(97.0)$ & $\begin{array}{c}45.6 \quad(97.6) \\
0.03\end{array}$ \\
\hline $\begin{array}{l}\text { Hemoglobin }(\mathrm{gm} / 100 \mathrm{ml}) \\
\text { p value }\end{array}$ & 16.2 & 16.3 & $(100.6)$ & 15.1 & (93.2) & 15.1 & $(93.2)$ & ${ }_{\mathrm{NS}}^{15.8}{ }^{(97.5)}$ \\
\hline $\begin{array}{l}\text { Systolic blood pressure } \\
\text { (mm Hg) } \\
\text { p value }\end{array}$ & 137.0 & 131.8 & $(96.2)$ & 132.8 & $(96.9)$ & 131.7 & $(96.1)$ & $\begin{array}{c}132.2 \quad(96.5) \\
\text { NS }\end{array}$ \\
\hline $\begin{array}{l}\text { Diastolic blood pressure } \\
\text { (mm Hg) } \\
\text { p value }\end{array}$ & 87.6 & 84.2 & $(96.1)$ & 83.2 & $(95.0)$ & 82.4 & $(94.1)$ & $\begin{array}{c}83.4 \quad(95.2) \\
0.03\end{array}$ \\
\hline \multicolumn{9}{|l|}{ Probenecid group } \\
\hline $\begin{array}{l}\text { Serum albumin } \\
\quad(\mathrm{gm} / 100 \mathrm{ml}) \\
\mathrm{p} \text { value }\end{array}$ & 4.29 & 4.06 & $(94.6)$ & 3.98 & $(92.8)$ & 3.77 & $(87.9)$ & $\begin{array}{l}3.97 \quad(92.5) \\
0.0009\end{array}$ \\
\hline $\begin{array}{l}\text { Hemoglobin }(\mathrm{gm} / 100 \mathrm{ml}) \\
\mathrm{p} \text { value }\end{array}$ & 16.5 & 16.1 & $(97.6)$ & 15.8 & $(95.8)$ & 15.7 & $(95.2)$ & ${ }_{\mathrm{NS}}^{15.9}(96.4)$ \\
\hline $\begin{array}{l}\text { Systolic blood pressure } \\
\text { (mm } \mathrm{Hg} \text { ) } \\
\text { p value }\end{array}$ & 144.2 & 141.4 & $(98.1)$ & 140.1 & $(97.2)$ & 140.8 & $(97.6)$ & $\begin{array}{c}140.8 \quad(97.6) \\
\text { NS }\end{array}$ \\
\hline $\begin{array}{l}\text { Diastolic blood pressure } \\
\text { (mm Hg) } \\
\text { p value }\end{array}$ & 95.0 & 93.6 & $(98.5)$ & 91.8 & $(96.6)$ & 91.2 & $(96.0)$ & $\begin{array}{c}92.3 \quad(97.2) \\
0.05\end{array}$ \\
\hline
\end{tabular}

Figures in parentheses $=\%$ of baseline value; $\mathrm{p}$ value is for baseline value vs period $\mathrm{A}$ to $\mathrm{C}$ value by paired $\mathrm{t}$ test.

the ophthalmologic and electrocardiographic findings.

In the probenecid group there were no significant changes in ideal weight or in serum triglycerides or cholesterol. As expected, probenecid induced a prompt decline in serum uric acid in period $A$ which was sustained throughout periods $\mathrm{B}$ and $\mathrm{C}$, averaging $30 \%$ for the entire treatment period $(p<0.0001)$.
In the patients receiving probenecid, there were significant reductions (Table III) in serum albumin ( $7.5 \%$ decline, periods $\mathrm{A}$ to $\mathrm{C}$ ), hemoglobin ( $4.5 \%$ decline, periods $\mathrm{B}$ and $\mathrm{C}$ ), and systolic and diastolic blood pressure (3\% decline in period B). There were no significant differences in the other biochemical or hematologic parameters or in the ophthalmologic and electrocardiographic parameters. 
Aside from leukopenia in one patient on halofenate and stomatitis in one patient on probenecid described above, there were no significant adverse effects during the study.

Comparison of the effects of halofenate and probenecid on certain parameters (between-group comparisons). To determine whether halofenate and probenecid exerted significantly different effects on serum triglycerides, cholesterol, and uric acid, the analytic approach involved a one-way analysis of covariance with one covariate. In this approach, the mean levels of triglycerides, cholesterol, uric acid, and percent ideal weight for each subject were computed for the baseline period and period $\mathrm{C}$. The difference between the two time periods for each parameter was computed, producing new variables: $\Delta$ triglycerides $(\Delta \mathrm{TG}), \Delta$ cholesterol $(\Delta \mathrm{CH}), \Delta$ uric acid ( $\Delta \mathrm{UA})$, and $\Delta$ percent ideal weight $(\Delta \% \mathrm{IW})$, respectively.

Because changes in percent ideal weight over time might affect serum triglyceride,$^{6}$ cholesterol, ${ }^{41}$ or uric acid, ${ }^{35}$ one-way analysis of covariance was performed with the use of $\Delta \mathrm{TG}$ (or $\Delta \mathrm{CH}$, or $\Delta \mathrm{UA}$ ) as the dependent variable, $\Delta \% \mathrm{IW}$ as the covariate, and the drug type as the factor to be considered. In other words, the change in serum triglyceride, cholesterol, or uric acid concentration ( $\triangle \mathrm{TG}, \Delta \mathrm{CH}, \Delta \mathrm{UA})$ from baseline period to period $C$ is compared, adjusting for possible changes in percent ideal weight between the same two time periods and testing whether the changes with halofenate were significantly different from those with probenecid.

These analyses revealed that there was no significant difference between halofenate and probenecid in their effects on serum cholesterol or uric acid in the two groups. There was, however, a significant difference $(p=0.006)$ in the case of serum triglycerides, with the halofenate group exhibiting lower values.

The same analytic approach was next adopted to determine whether intergroup differences in serum triglyceride concentration were noted between baseline and period $A$ and baseline and period $\mathrm{B}$ and between periods $\mathrm{A}$ and $\mathrm{B}, \mathrm{A}$ and $\mathrm{C}$, and $\mathrm{B}$ and $\mathrm{C}$. There were no significant differences in the effects of halofenate and probenecid in any of these shorter time period comparisons. Thus it appears that the difference in the effect of the two drugs on serum triglycerides becomes more marked with time, reaching statistical significance in 44 to $56 \mathrm{wk}$ of treatment. Both drugs reduced the level of serum triglycerides initially, but the halofenate group maintained this reduced level while the serum triglycerides in the probenecid group rose above baseline after period A.

Comparison of halofenate with probenecid: Effects on other parameters (between-group comparisons). With the use of the same approach, analyses were conducted to compare the effects of halofenate and probenecid on those other biochemical, hematologic, and hemodynamic parameters described above in which inspection of the within-group mean values for each parameter followed over time suggested the possibility of differential effect.

Analyzing the effects on serum LDH, the mean difference (baseline to period $\mathrm{C}$ ) for group $\mathrm{H}$ was $20.5 \mathrm{IU}$ ( $12.1 \%$ increase), while that for the probenecid group (group $\mathrm{P}$ ) decreased 34.4 IU $((\mathrm{p}=0.0005)$ with MannWhitney $U$ test, since the data were skewed). With the use of the same approach, betweengroup comparisons of fasting serum glucose, total protein, albumin, bilirubin, hematocrit, hemoglobin, and systolic and diastolic blood pressure revealed no statistically significant differences.

Relationship of initial serum lipid, uric acid, or percent ideal weight level to subsequent responses to drug therapy (between-group analyses). To determine whether the drug effect on serum triglycerides, cholesterol, or uric acid might be a function of the initial level of these variables (or of percent ideal weight), the effects of halofenate and probenecid were compared. The median baseline levels (within groups $\mathrm{H}$ and $\mathrm{P}$ separately) of serum triglycerides, cholesterol, uric acid, and percent ideal weight were determined, and then, within each drug group, each individual was assigned to either the high or the low stratum. Finally, a series of two-way analyses of covariance were performed on the dependent variables $\triangle \mathrm{TG}, \Delta \mathrm{CH}$, and $\triangle \mathrm{UA}$ with one covariate $(\Delta \% \mathrm{IW})$ and two factors (level $=$ 
high or low and drug type $=\mathbf{H}$ or $\mathrm{P}$ ). These analyses* revealed: (1) the expected "drug effect" due to halofenate (Table II) when the response variable was serum triglycerides and baseline was compared with period C; (2) a differential high-low effect was noted when the variable was serum uric acid and again when the variable was percent ideal weight. In the former, a differential response was noted in two response variables (serum triglycerides and uric acid), while in the latter a differential response was noted only in serum triglycerides. These responses were evident when baseline and period $\mathrm{C}$ data were compared and also when baseline data were compared with all treatment periods combined. In all cases, there was a greater effect (a greater decline) in the "high" halofenate group than in the "low" halofenate group. Likewise, there was a greater decline (or a lesser increase) in the "high" probenecid group than in the "low" probenecid group. This was noted when both uric acid and percent ideal weight were the segregating variables. The greatest difference in halofenate effect was noted when percent ideal weight was the segregating variable; in the baseline/period $\mathrm{C}$ comparison, the "high" halofenate group experienced a $25.5 \%$ decline in serum triglycerides, whereas in the "low" halofenate group there was a $2.7 \%$ rise in serum triglycerides. When the halofenate group was segregated on baseline serum uric acid level, there was a $22.6 \%$ reduction in the "high" group, whereas there was a $2.4 \%$ reduction in serum triglycerides in the "low" group between baseline and period $\mathrm{C}$.

Relationship of certain dietary and disease variables to percent change in triglycerides and percent change in ideal body weight (intragroup comparisons). Because the average percent reduction in serum triglycerides in group $\mathrm{H}$ was considerably less than that reported by others and because of the wide variability in the $\Delta \mathrm{TG}$ (baseline to period $\mathrm{C}$; range $=-48.3 \%$ to $+34.1 \%$ ), certain other variables which might also affect serum triglyceride level were examined by scatter plots and analysis of correlation coefficients. In

\footnotetext{
*A table summarizing these results is filed in the permanent files of The C. V. Mosby Company. See footnote on page 343.
}

group $\mathrm{H}$, there was a correlation between $\% \Delta \mathrm{TG}$ and \% calories from alcohol; in group $\mathrm{P}$ there was a correlation between $\% \Delta \mathrm{TG}$ and $\% \Delta \mathrm{IW}(\mathrm{p}<0.05$ for both).*

\section{Discussion}

Others have reported ${ }^{1-5,}, 9,17,21-22,24,26,29$, $31,33,36,38-40,46,47$ that the principal clinically significant effects of halofenate were on fasting serum triglyceride and uric acid concentrations. In our study, the halofenate group averaged a $12.7 \%$ decline in serum triglycerides (range, $-48.3 \%$ to $+34.1 \%$ ) which was evident within $2 \mathrm{wk}$ and sustained over $48 \mathrm{wk}$. The decline in serum triglycerides was generally dependent (though not in a linear fashion) on the initial percent ideal body weight and the initial serum uric acid level. It was not significantly related to the initial serum triglyceride or to cholesterol concentration. While careful efforts were made to assure constant weight in subjects throughout the study and while the average weights remained within \pm 10 pounds of starting weight in $87 \%$ of subjects, even this weight change had an effect on the triglyceride values. Analysis of individual $\Delta T G$ values revealed a significant relationship to change in weight in group $P$ but not in group $\mathrm{H}$ (suggesting that the effect of halofenate overrides the expected relationship between $\Delta \mathrm{TG}$ and $\Delta \mathrm{IW}$ ) and in group $\mathrm{H}$ to percent alcohol intake in baseline.

Halofenate induced a $31 \%$ decline in serum uric acid which was evident within 2 wk and sustained over the entire treatment period. The uric acid effect was essentially identical to that achieved with probenecid. Other studies ${ }^{22,24,33}$, 36,46 have demonstrated that the decline in serum uric acid concentration results from the uricosuric effect of halofenate. Our study indicates that the degree of reduction in serum uric acid with both halofenate and probenecid is related to the initial serum uric acid concentration and in the probenecid group also correlates with the baseline percent ideal weight.

Halofenate induced a transitory decline in serum cholesterol $(6.0 \%)$ at $2 \mathrm{wk}$, followed by

\footnotetext{
*A more detailed description of these analyses is filed in the permanent files of The C. V. Mosby Company. See footnote on page 343 .
} 
an immediate return to baseline resulting in no significant overall effect.

Changes were noted (on intragroup analysis) in the halofenate group in fasting serum glucose, protein, albumin, bilirubin, hematocrit, hemoglobin, systolic and diastolic blood pressures (declines), and serum LDH (elevation) and in the probenecid group in serum albumin, hemoglobin, and systolic and diastolic blood pressures (declines). When intergroup comparisons were performed, the only significant difference was in serum LDH (with halofenate producing a greater percent increase).

The reduction of serum glucose by halofenate was shown not to be related to the taking of sulfonylurea drugs by patients in the halofenate group..$^{25}$ (Only one subject was taking tolbutamide; exclusion of data on the subject did not materially alter the serum glucose responses.) The lowered serum glucose may result from a reduced insulin/glucagon ratio. ${ }^{13}$

The lowering of serum bilirubin concentration in the halofenate group already reported by others ${ }^{21}, 22,33,40$ was of similar magnitude and is considered to be due to the vigorous binding of halofenate to albumin ${ }^{12,14,20,42,43,45}$ which in turn decreases the binding of organic compounds such as bilirubin, ${ }^{23,}{ }^{44,}{ }^{48}$ resulting in increased bilirubin clearance and decreased serum bilirubin concentration.

The effect of halofenate on serum protein and albumin concentrations may be due to its effect in reducing amino acid incorporation into protein, as shown by Homcy and Margolis ${ }^{19}$ with the use of ${ }^{14} \mathrm{C}$-leucine incorporation. This effect does not appear to be explicable entirely by hemodilution, since the hemoglobin concentration with halofenate was slightly higher than that with probenecid, but in view of the lowering of hemoglobin observed in both treatment groups a contributory role of hemodilution is not ruled out. Support for hemodilution as a factor is the finding that in diabetes insipidus halofenate has an antidiuretic effect ${ }^{16}$ similar to that of clofibrate. ${ }^{34}$

In our study, there was a small increase in percent ideal body weight in the halofenate group, rising in the final $12 \mathrm{wk}$ of therapy to $3.1 \%$ above control and averaging $2.2 \%$ over the entire 48-wk treatment period. These weight changes did not differ significantly from the weight gain in the probenecid group. When the values for the 2 subjects (one diabetic) who gained more than $5 \%$ of ideal weight in the halofenate group are excluded, the percent change averaged +1.4 . When the values for the 2 subjects (one diabetic) who gained more than $5 \%$ ideal weight in the probenecid group are excluded, the percent change averaged -0.7 .

An increase in body weight has been reported in outpatients taking clofibrate, ${ }^{11}$ which has been shown not to be due to fluid retention ${ }^{30}$ and is postulated ${ }^{30}$ to represent increased adipose tissue mass. More study involving repeated assessment of caloric intake and energy expenditure and measurement of percent adipose mass is required to resolve the question whether and how halofenate induces weight gain in subjects at isocaloric status.

Only Morgan and co-workers ${ }^{33}$ and Hutchinson and Wilkinson ${ }^{21,}{ }^{22}$ have reported on the effect of halofenate on LDH responses. They found, contrary to our detection of a significant elevation $(13.3 \%$ for all study periods combined), that it did not change. LDH is found in all tissues, especially in myocardium, kidney, liver, and muscle. The mechanism for the observed increase is not yet known. Others have reported elevations in $\mathrm{SGOT}^{1,2,4}$ and serum CPK. ${ }^{1,2,4,21}$ Whether these changes represent hepatic, muscle, or other tissue response is not yet known.

In an attempt to determine why the average percent reduction in serum triglyceride concentration is smaller in this study than in many others, all relevant studies were reviewed and results tabulated to enable comparison of studies of the multiple factors. Because changes in weight can produce changes in serum triglycerides, ${ }^{6}$ cholesterol, ${ }^{41}$ or uric acid,${ }^{35}$ valid comparisons were possible only in studies which indicated whether weight changes occurred. Only four studies ${ }^{22,29,33,36}$ indicated the weight status at the end of the study (all stated that there had been no weight change), but no values for weight at the close of study are given and none indicate the subject's degree of overweight. In these studies, all administered 1.0 
$\mathrm{gm} /$ day halofenate. The duration of studies and the percent decline in serum triglycerides were: Morgan and associates, ${ }^{33} 6 \mathrm{wk}, 50 \%$ decrease; Ravenscroft and co-workers, ${ }^{36} 9$ days, $26 \%$ decrease; Hutchinson and colleagues, ${ }^{22} 4 \mathrm{wk}$, $16 \%$ decrease (reported, ". . . no significant change in triglycerides due to wide range of values"); Lisch and associates, ${ }^{29} 48 \mathrm{wk}, 47 \%$ decline during the second 24 -wk period in 6 type IV patients. Statistical analysis ${ }^{29}$ was done by means of Student's $t$ test, with "treatment period results" compared with baseline. It is unclear whether a paired $t$ test was used, and no allowance appears to have been made for the skewed triglyceride distribution. Nevertheless, the graphic presentation of the mean data appears significant. Our findings (see "Results" section) are likely to reveal the principal reasons for the differences reported in various studies, i.e., the importance of the percent ideal weight, serum uric acid, and alcohol intake in determining the degree of triglyceride reduction.

Only a few studies have been published which describe mechanisms by which halofenate might lower serum triglyceride concentrations. Homcy and Margolis ${ }^{19}$ reported on the comparative effects of halofenate and clofibrate on acetate and fatty acid oxidation and on lipid and protein synthesis in isolated rat hepatocytes. Halofenate was 30 times as potent in decreasing lipid synthesis from ${ }^{14} \mathrm{C}$-acetate; it also inhibited ${ }^{14} \mathrm{C}$-leucine incorporation into protein. These workers proposed, based on earlier work, ${ }^{12}, 14,20,42,43,45$ that displacement by the drug of fatty acid from albumin was responsible for its principal effects. Greenspan and associates ${ }^{18}$ compared the effects of halofenate and clofibrate on lipid synthesis in isolated rat adipocytes and found these drugs to inhibit the incorporation of tagged glucose and pyruvate into adipose fatty acids. The strong tendency for halofenate to bind to albumin appears to be the basis, and possibly the sole basis, for the effects of halofenate noted in relation to thyroid hormone and related compounds, ${ }^{12}$ bilirubin ${ }^{21}$, 22, 33, 40 and sulfonylureas. ${ }^{25}$ Additional reactions which must be considered in the use of halofenate as a pharmacotherapeutic agent include the significance of its effect on serum
CPK, SGOT, and LDH, the mechanisms of its decreased beta blockade effect, ${ }^{28}$ and the mechanism of its effect in decreasing platelet aggregation. ${ }^{27}$

The principal contribution of our work is the demonstration of the relationship of initial percent ideal body weight to subsequent response in serum triglyceride concentration to halofenate and probenecid, and the relationship of initial serum uric acid concentration to subsequent serum triglyceride and uric acid response to halofenate and probenecid. The approach taken here is one way of considering the law of the initial value. ${ }^{49}$ Workers undertaking similar studies of the effects of this or similar drugs should carefully evaluate the degree of overweight and of relative adipose mass and should assure that weight is kept constant and is reported in such studies. Analyses should be made of drug dosage, caloric intake, nutrient intake, and energy expenditure and their effects on serum lipids and uric acid. Only when this is done will it be possible to draw firm conclusions on the effectiveness of halofenate (or of any drug) in hyperlipidemic or hyperuricemic patients.

We gratefully acknowledge Marlene J. Winchester for office management relating to study, Beverly $M$. Steinke for coordination of patient scheduling and data recording, George Kunkel, M.D., for clinical evaluation of some patients, C. J. Davis, M.D., for ophthalmologic examinations, K. John Jarrett, M.P.H., for serum lipid analyses, Joan E. Himes for uric acid analyses, and William $\mathrm{H}$. Mikkelsen for coding and initial processing of data.

\section{References}

1. Aronow, W. S., Harding, P. R., Khursheed, M., Vangrow, J. S., Papageorge's, N. P.: Effect of halofenate on serum uric acid, Clin. Pharmacol. Ther. 14:371-343, 1973.

2. Aronow, W. S., Harding, P. R., Khursheed, M., Vangrow, J. S., Papageorge's, N. P., and Mays, J.: Effect of halofenate on serum lipids, Clin. Pharmacol. Ther. 14:358-365, 1973.

3. Aronow, W. S., Vangrow, J. S., Nelson, W. H., et al.: Halofenate, serum lipids, and exercise performance in coronary heart disease, CLIN. Pharmacol. Ther. 15:67-72, 1974.

4. Aronow, W. S., Vangrow, J. S., Nelson, W. H., Pagano, J., Papageorge's, N. P., Khursheed, M., Harding, P. R., and Khemka, M.: Halofenate: An effective hypolipemia and 
hypouricemia-inducing drug, Curr. Ther. Res. 15:902-906, 1973.

5. Beaumont, V., Buxtorf, J. C., Jacotot, B., and Beaumont, J. L.: Comparative study of several hypolipidemic agents related to clofibrate, Atherosclerosis 20:141-153, 1974.

6. Blacket, R. B., Leelarthaepin, B., Woodhill, J. M., and Palmer, A. J.: Type IV hyperlipidemia and weight gain after maturity, Lancet 2:517520,1975 .

7. Block, W. D., and Jarrett, K. J.: An automated technique for the quantitative determination of serum total triglycerides, Am. J. Med. Techn. 35:93-102, 1969 .

8. Block, W. D., Jarrett, K. J., Jr., and Levine, J. B.: An improved automated determination of serum total cholesterol with a single color reagent, Clin. Chem. 12:681-689, 1966.

9. Bluhm, G. B., and Riddle, J. M.: Platelets and vascular disease in gout, Semin. Arthritis Rheum. 2:355-366, 1973.

10. Brown, $H .:$ The determination of uric acid in human blood, J. Biol. Chem. 158:601-608, 1945.

11. The Coronary Drug Project Research Group: Clofibrate and niacin in coronary heart disease, J. A. M. A. 231:360-381, 1975.

12. Davis, P. J., Hsu, T. H., Bianchine, J. R., and Morgan, J. P.: Effects of a new hypolipidemic agent, MK-185, on serum thyroxine-binding globulin (TBG) and dialyzable fraction thyroxine, J. Clin. Endocrinol. Metab. 34:200$208,1972$.

13. Eaton, R. P., Oase, R., and Schade, D. S.: Altered insulin and glucagon secretion in treated genetic hyperlipemia: A mechanism of therapy? Metabolism 25:245-249, 1976.

14. Fletcher, J. E., and Ashbrook, J. D.: Computer analysis of drug-protein binding data, Ann. N. Y. Acad. Sci. 226:69-81, 1973.

15. Fredrickson, D. S., Levy, R. I., and Lees, R. S.: Fat transport in lipoproteins-an integrated approach to mechanisms and disorders, N. Engl. J. Med. 276:34-42, 94-103, 148-156, 215-225, 273-281, 1967.

16. Gattereau, A., Davignon, J., Verdy, M., and Lewis, W.: Halofenate vs. clofibrate in the management of true diabetes insipidus, Can. Med. Assoc. J. 110:1275-1277, 1974.

17. Gilfillan, J. L., Hunt, V. M., and Huff, J. W.: The hypolipidemic properties of 2-acetoamidoethyl (p-chlorophenyl) (m-trifluromethylphenoxy) acetate in the rat (35474), Proc. Soc. Exp. Biol. Med. 136:1274-1276, 1971.

18. Greenspan, M. D., Germershausen, J. I., and Mackow, R.: Effect of halofenate and clofibrate on lipid synthesis in rat adipocytes, Biochim. Biophys. Acta 380:190-198, 1975.

19. Homcy, C. J., and Margolis, S.: Comparison of the effects of clofibrate and halofenate (MK-
185) in isolated rat hepatocytes, Atherosclerosis 19:381-391, 1974.

20. Hucker, H. B., Grady, L. T., Michiewicz, B. M., et al., Metabolism of a new hypolipidemic agent 2-acetamido-ethyl (p-chlorophenyl) (mtrifluoromethyl phenoxy)-acetate (halofenate) in the rat, dog, rhesus monkey and man, J. Pharmacol. Exp. Ther. 179:359-371, 1971.

21. Hutchison, J. C., and Wilkinson, W. H.: Halofenate: Effectiveness of two dosage forms and two dose schedules, Atherosclerosis 19: 417-428, 1974

22. Hutchison, J. C., and Wilkinson, W. H.: The uricosuric action of halofenate (MK-185) in patients with hyperuricemia or uncomplicated primary gout and hyperlipidemia, Atherosclerosis 18:353-362, 1973.

23. Jacobsen, C.: Chemical modification of the high-affinity bilirubin binding site of human serum albumin, Eur. J. Biochem. 27:513-519, 1972.

24. Jain, A., Ryan, J. R., Hague, D., McMahon, F. G.: The effect of MK-185 on some aspects of uric acid metabolism, Clin. Pharmacol. THER. 11:551-557, 1970.

25. Jain, A. K., Ryan, J. R., and McMahon, F. G.: Potentiation of hypoglycemic effect of sulfonylureas by halofenate, N. Engl. J. Med. 293: 1283-1286, 1975.

26. Jepson, E. M., Small, E., Grayson, M. F., Bance, G., and Billimoria, J. D.: A comparative study of a new drug MK-185 with clofibrate in the treatment of hyperlipidemias, Atherosclerosis 16:9-14, 1972 .

27. Kritchevsky, D.: New drugs affecting lipid metabolism, Lipids 9:97-102, 1974.

28. Lewis, N. J., Witiak, D. T., and Feller, D. R.: Influence of clofibrate (ethyl-4-chlorophenoxyisobutyrate) on hepatic drug metabolism in male rats (37793), Proc. Soc. Exp. Biol. Med. 145:281-285, 1974

29. Lisch, H. J., Patsch, J., Sailer, S., and Braunsteiner, H.: Comparison of the effects of halofenate (MK-185) and clofibrate on plasma lipid and uric acid concentration in hyperlipoproteinemic patients, Atherosclerosis 21:391. 399, 1975.

30. MacMillan, D. C., Oliver, M. F., Simpson, J. D., and Tothill, P.: Effect of ethyl-chlorophenoxyisobutyrate on weight, plasma volume, total body-water, and free fatty acids, Lancet 2:924-926, 1965.

31. McMahon, F. G., Jain, A., Ryan, J. R., Hague, D.: Some effects of MK-185 on lipid and uric acid metabolism in man, Univ. Mich. Med. J. 36:247-248, 1970.

32. Metropolitan Life Insurance Company: Desirable weights for men and women, Stat. Bull. Metropol. Life Ins. Co. 40:3, 1959.

33. Morgan, J. P., Bianchine, J. R., Hsu Tah- 
Hsiung, and Margolis, S.: Hypolipidemic, uricosuric, and thyroxine-displacing effects of MK-185 (halofenate), Clin. Pharmacol. THER. 12:517-524, 1971 .

34. Moses, A. M., Howanitz, J., Van Gemert, M., and Miller, M.: Clofibrate-induced antidiureses, J. Clin. Invest. 52:535-542, 1973.

35. Nicholls, A., and Scott, J. T.: Effect of weightloss on plasma and urinary levels of uric acid, Lancet 2:1223-1224, 1972.

36. Ravenscroft, P. J., Sands, J. M., and Emmerson, B. T.: Studies of the uricosuric action of the hypolipidemic drug halofenate, Clin. PHARMACOL. THER. 14:547-551, 1973.

37. Reagent data handbook SMA 1260 system, Technicon Publication THO-0160-10, Technicon Co., Tarrytown, N. Y., 1971.

38. Ryan, J. R.: The metabolic spectrum of halofenate, Int. J. Clin. Pharmacol. Biopharm. 12: 239-243, 1975.

39. Schlosstein, L. H., Kippen, I., Whitehouse, M. W., Bluestone, R., Paulus, H. E., and Klinenberg, J. R.: Studies with some novel uricosuric agents and their metabolities: Correlation between clinical activity and drug-induced displacement of urate from its albumin-binding sites, J. Lab. Clin. Med. 82:412-418, 1973.

40. Sirtori, C., Hurwitz, A., Sabih, K., and Azarnoff, D. L.: Clinical evaluation of MK-185: A new hypolipidemic drug, Lipids 7:96-99, 1972.

41. Sodhi, H. S., Kudchodkar, B. J., and Horlick, L.: Effects of caloric restriction on cholesterol metabolism in hyperlipidemic obese subjects, Circulation 52:II-117, 1975.
42. Spector, A. A.: Fatty acid binding to plasma albumin, J. Lipid Res. 16:165-179, 1975.

43. Spector, A. A., and Santos, E. C.: Influence of free fatty acid concentration on drug binding to plasma albumin, Ann. N. Y. Acad. Sci. 226:247-258, 1973.

44. Thiessen, H., Jacobsen, J., and Brodersen, R.: Displacement of albumin-bound bilirubin by fatty acids, Acta Paediatr. Scand. 61:285-288, 1972.

45. Whitehouse, M. W., Kippen, I., and Klineberg, J. R.: Biochemical properties of anti-inflammatory drugs. XII, Biochem. Pharmacol. 20: 3309-3320, 1971.

46. Whitehouse, M. W., Kippen, I., Klineberg, J. R., Schlosstein, L., Campion, D. S., and Bluestone, R.: Increasing excretion of urate with displacing agents in man, Ann. N. Y. Acad. Sci. 226:309-318, 1973

47. Wolfram, G., Keller, C., et al.: First clinical experiences in therapy of hyperuricemia and hyperlipidemia with the clofibrate derivative MK-185, Verh. Dtsch. Ges. Inn. Med. 79: 1291-1293, 1973.

48. Woolley, P. V., III, and Hunter, M. J.: Binding and circular dichroism data on bilirubin-albumin in the presence of oleate and salicylate, Arch. Biochem. Biophys. 140:197-209, 1970.

49. Wilder, J.: Basimetric approach (law of initial value) to biological rhythms, Ann. N. Y. Acad. Sci. 98: $1211,1962$. 